THE SPIKE 


$$
\text { L }
$$




\title{
THE SPIKE
}

A N E I C JOURNEY

THROUGH THE BRA I N

I N 2.1 S E CONDS

MARK H U M P R IES

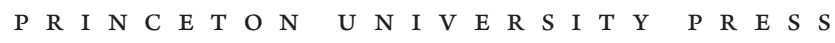

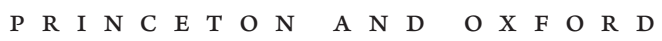




\section{Copyright $\left({ }^{\circ} 2021\right.$ by Mark Humphries}

Princeton University Press is committed to the protection of copyright and the intellectual property our authors entrust to us. Copyright promotes the progress and integrity of knowledge. Thank you for supporting free speech and the global exchange of ideas by purchasing an authorized edition of this book. If you wish to reproduce or distribute any part of it in any form, please obtain permission.

Requests for permission to reproduce material from this work should be sent to permissions@press.princeton.edu

Published by Princeton University Press

41 William Street, Princeton, New Jersey o8540

6 Oxford Street, Woodstock, Oxfordshire OX20 1TR

press.princeton.edu

All Rights Reserved

ISBN 978-0-691-19588-9

ISBN (e-book) 978-o-691-21351-4

British Library Cataloging-in-Publication Data is available

Editorial: Hallie Stebbins and Kristen Hop

Production Editorial: Brigitte Pelner

Jacket Design: Karl Spurzem

Production: Jacqueline Poirier

Publicity: Sara Henning-Stout (US) and Kate Farquhar-Thomson (UK)

Copyeditor: Dawn Hall

This book has been composed in Arno Pro with League Mono display

Printed on acid-free paper $\infty$

Printed in the United States of America

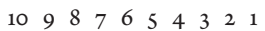


To Nic, Abbi, and Seth 
